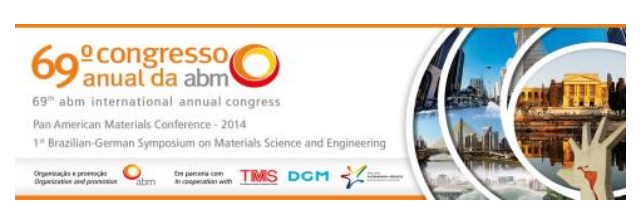

Theme: Phase diagrams and phase transformations

\title{
SOLID OXIDE FUEL CELL (SOFC) WITH CU-CERIA ANODE RUNNING ON METHANE OR BIOGAS MIXTURES: THERMODYNAMIC ANALYSIS*
}

Aline Lima da Silva ${ }^{1}$ Nestor Cezar Heck²

\begin{abstract}
The present work is focused on the thermodynamic study of the methane or biogas mixtures conversion on Cu-ceria catalysts. Several experimental studies reported in literature have demonstrated the ability of these materials to operate as SOFC anodes for direct methane oxidation, with the evidence of enhanced tolerance towards sulfur poisoning and carbon deposition. More recently, experimental investigations have shown the feasibility of $\mathrm{Cu}$-ceria anodes to directly operate with simulated biogas feeds at intermediate temperature (1023K). In this way, the effect of the ceria redox properties on the equilibrium composition is investigated, considering methane or biogas mixtures as the fuel. Conditions under which carbon deposition and sulfur poisoning can be prevented are determined. Our study combines results from the classical thermodynamics, obtained with the help of FactSage software, with the new Cu-S and Ni-S diagrams proposed in literature, which were calculated based on the Density Functional Theory (DFT). These diagrams are able to predict a region where sulfur interacts with the metal surface through chemisorption. A comparison between the performances of $\mathrm{Ni}-\mathrm{YSZ}$ and $\mathrm{Cu}-\mathrm{CeO}_{2}$ catalysts is established from a thermodynamic viewpoint. Theoretical results are in agreement with the experimental trends from literature.
\end{abstract}

Keywords: SOFC; Ceria; Sulfur poisoning; Methane.

1 Metallurgical Engineer, Dr., Postdoctoral Researcher, Núcleo de Termodinâmica Computacional para a Metalurgia (NTCm), Depto. de Metalurgia, PPGE3M, UFRGS, Porto Alegre, RS, Brasil; adasilva26@gmail.com.

2 Metallurgical Engineer, Dr., Professor, Núcleo de Termodinâmica Computacional para a Metalurgia (NTCm), Depto. de Metalurgia, PPGE3M, UFRGS, Porto Alegre, RS, Brasil; heck@ufrgs.br.

* Technical contribution to the 69th $A B M$ International Annual Congress and to the ENEMET, July $21^{\text {st }}-25^{\text {th }}$, 2014, São Paulo, SP, Brazil. 


\section{INTRODUCTION}

Biogas is an attractive renewable energy source which is produced by anaerobic digestion of the organic matter [1]. It is mainly constituted by $\mathrm{CH}_{4}$ and $\mathrm{CO}_{2}$, containing trace amounts of $\mathrm{NH}_{3}, \mathrm{H}_{2} \mathrm{~S}$ and halides. Biogas composition fluctuates significantly during its production and it is highly dependent of the substrate used for the production process [2]. The high operation temperature of Solid Oxide Fuel Cells (SOFCs) makes direct internal reforming of biogas possible. In this case, the reforming reaction takes place directly, without the necessity of an external reformer, on the SOFC anode, simultaneously with the charge transfer reactions, i.e., $\mathrm{H}_{2}$ and $\mathrm{CO}$ oxidations by $\mathrm{O}^{2-}[3]$. However, one of the great challenges to be overcome is the development of materials with enhanced tolerance towards sulfur poisoning and carbon deposition. The traditional Ni-YSZ (yttria-stabilized zirconia) can be severely poisoned by sulfur-containing compounds. In addition, $\mathrm{Ni}$ also catalyzes the carbon deposition reaction from carbonaceous fuels, such as hydrocarbons [4]. In this context, the Ni phase in Ni-YSZ cermet anodes could be replaced by other metals that have lower affinity for sulfur. It is well known that copper has much less affinity for sulfur adsorption [4]. The problem of low catalytic activity of Cu can be overcome by the incorporation of ceria into the Cu-based anode [5-7].

In this way, the present work aims at investigating the effect of ceria redox properties on the equilibrium composition, considering methane or biogas mixtures as a fuel in the SOFC anodes. Conditions under which carbon deposition and sulfur poisoning can be simultaneously prevented are determined. In the present study, we have also established a comparison between the performances of $\mathrm{Ni}-\mathrm{YSZ}$ and $\mathrm{Cu}-\mathrm{CeO}_{2}$ catalysts from a thermodynamic viewpoint. Theoretical results are compared with experimental trends reported in the literature.

\section{SIMULATION METHODOLOGY}

\subsection{Gibbs Energy Minimization Method and Databases}

Thermodynamic equilibrium calculations using the Gibbs energy minimization approach were carried out using the commercial software FactSage 6.3. The Equilib module determines through a minimization routine the different values of number of moles, molar fraction and partial pressure that minimize the objective function (Gibbs energy of the system), subject to the elemental mass balance constraints [8]. Table 1 shows the databases and species considered in the thermodynamic calculations. A detailed description of FactSage thermochemical software and databases can be seen in Refs. [9-11].

\footnotetext{
* Technical contribution to the $69^{\text {th }} A B M$ International Annual Congress and to the ENEMET, July $21^{\text {st }}-25^{\text {th }}$, 2014, São Paulo, SP, Brazil.
} 
can be gasified exclusively by the Oxygen Storage Capacity (OSC) of ceria. When exposed to a reducing atmosphere, $\mathrm{CeO}_{2}$ is reduced to its non-stoichiometric $\mathrm{CeO}_{2-x}$ form. In this way, solid carbon is gasified due to the release of lattice oxygen. From the experimental study reported by Chen et al. [13], one can see that a much reduced addition of steam (only 10 vol\% steam addition) was sufficient to fully suppress carbon deposition over $\mathrm{CeO}_{2}$-modified $\mathrm{Ni}$-YSZ anode operated under OCV conditions on methane fuel at $1123 \mathrm{~K}$. In contrast, in absence of $\mathrm{CeO}_{2}$, for a conventional Ni-YSZ, carbon deposition was prevented at temperatures greater than $1223 \mathrm{~K}$ with a high inlet steam/methane molar ratio of $3: 1$, as verified in the experimental research reported by Laosiripojana et al. [14]. Thus, the benefits of ceria addition to SOFC anodes are clearly shown by theoretical analysis and experimental evidences. From Figure 1 (a) and (b), one can see that, when both inlet $\mathrm{H}_{2} \mathrm{O}$ /methane and $\mathrm{CeO}_{2} /$ methane molar ratio assume low values, the system is composed essentially by $\mathrm{H}_{2}$ (partial pressure greater than 0.9 ) and solid carbon, due to methane decomposition reaction $\left(\mathrm{CH}_{4}=\mathrm{C}+2 \mathrm{H}_{2}\right)$. Interestingly, the gas phase becomes richer in $\mathrm{CO}$ as the inlet $\mathrm{CeO}_{2} /$ molar ratio increases, as can be seen in Figure 1(c). From Figure 2, one can see that at high inlet $\mathrm{CeO}_{2} /$ methane molar ratios and lower inlet $\mathrm{H}_{2} \mathrm{O}$ /methane molar ratios, the $\mathrm{H}_{2} / \mathrm{CO}$ equilibrium ratio approaches 2 , in agreement with the partial oxidation reaction of methane $\left(\mathrm{CH}_{4}+0.5 \mathrm{O}_{2}=\mathrm{CO}+2 \mathrm{H}_{2}\right)$. Note that the partial oxidation of methane is taking place due to the release of lattice oxygen of ceria $\left(O_{x}=\left(\frac{1}{2}\right) O_{2}+V_{\ddot{o}}+2 e^{\prime}\right)$. Electrons (e') are generated by the ceria reduction reaction. For this reason, doped-ceria can be referred as mixed ionicelectronic conductor. At an inlet $\mathrm{H}_{2} \mathrm{O}$ /methane molar ratio of approximately 1 , the $\mathrm{H}_{2} / \mathrm{CO}$ molar ratio at equilibrium is near 3 , independently of the $\mathrm{CeO}_{2}$ amount in the system, which is consistent with the steam reforming reaction $\left(\mathrm{CH}_{4}+\mathrm{H}_{2} \mathrm{O}=\mathrm{CO}+3 \mathrm{H}_{2}\right)$.

* Technical contribution to the $69^{\text {th }}$ ABM International Annual Congress and to the ENEMET, July $21^{\text {st }}-25^{\text {th }}$, 2014, São Paulo, SP, Brazil. 


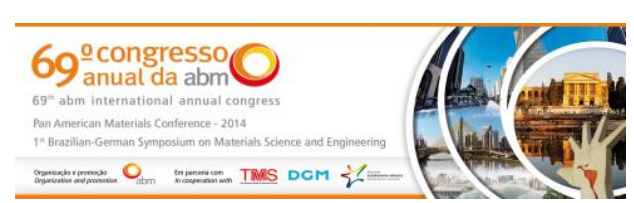

(a)

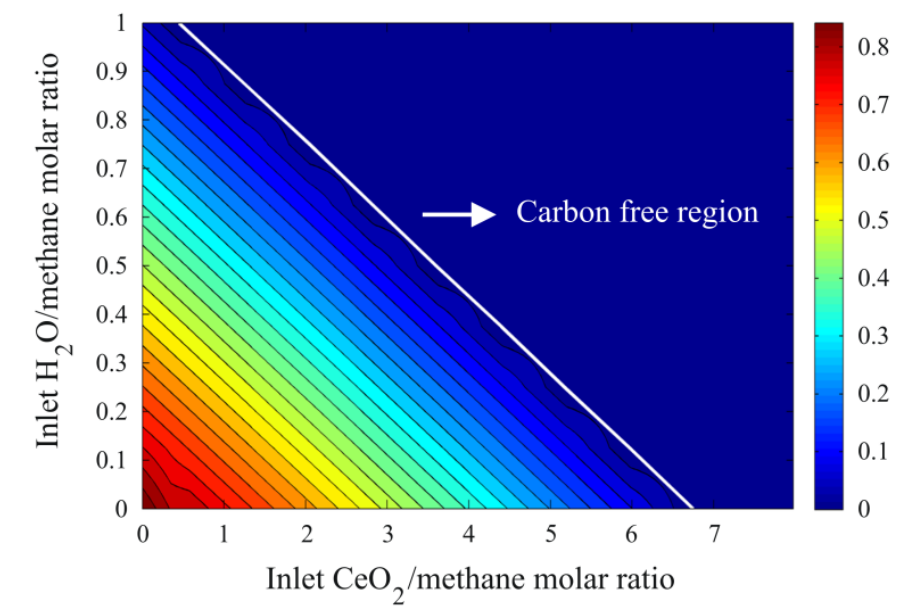

(b)

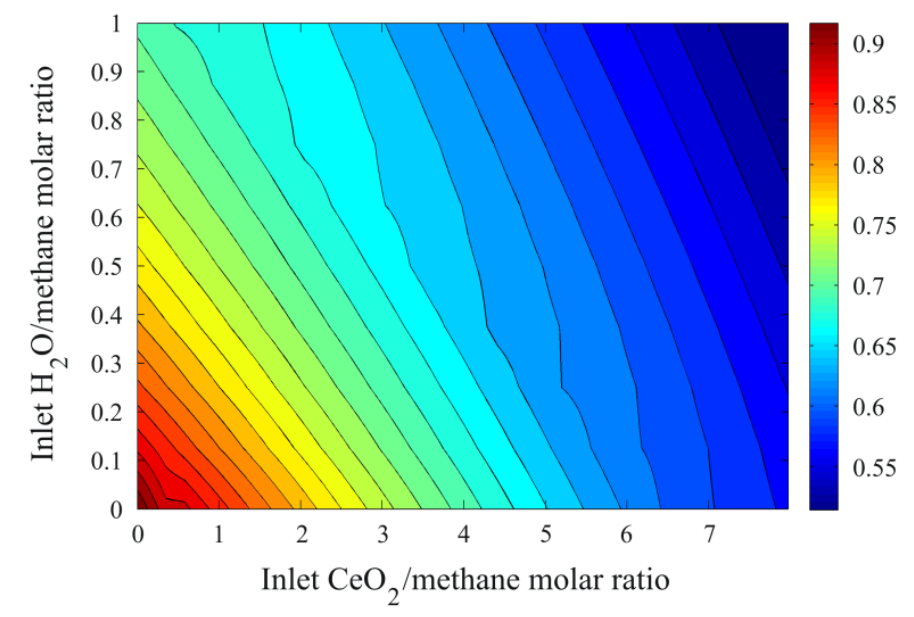

(c)

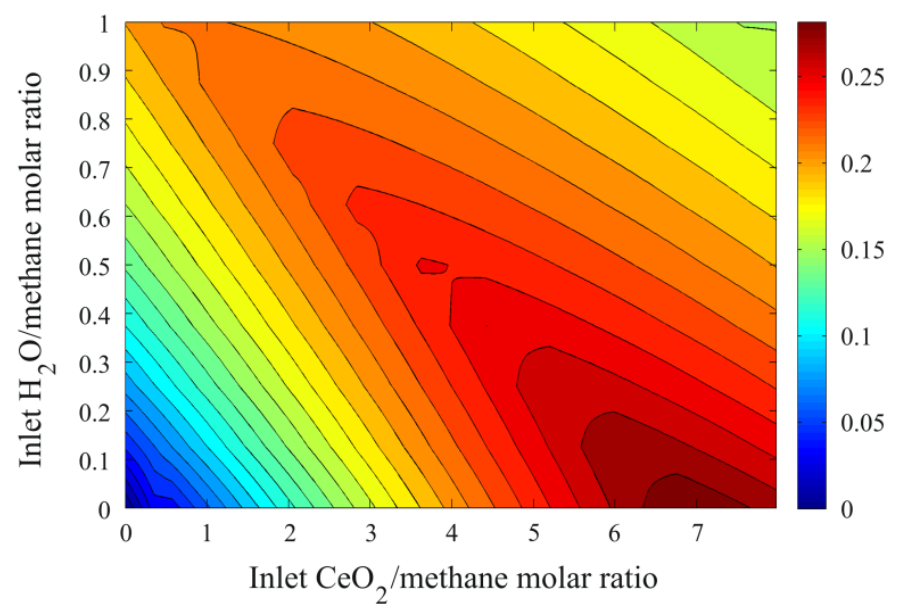

Figure 1. Effect of inlet $\mathrm{H}_{2} \mathrm{O}$ /methane and $\mathrm{CeO}_{2} /$ methane molar ratios on moles of solid carbon (a), partial pressure of $\mathrm{H}_{2}$ (b) and partial pressure of $\mathrm{CO}$ (c). $T=1023 \mathrm{~K}$. The thick white line in (a) stands for carbon deposition boundary.

* Technical contribution to the $69^{\text {th }}$ ABM International Annual Congress and to the ENEMET, July $21^{\text {st }}-25^{\text {th }}$, 2014, São Paulo, SP, Brazil. 


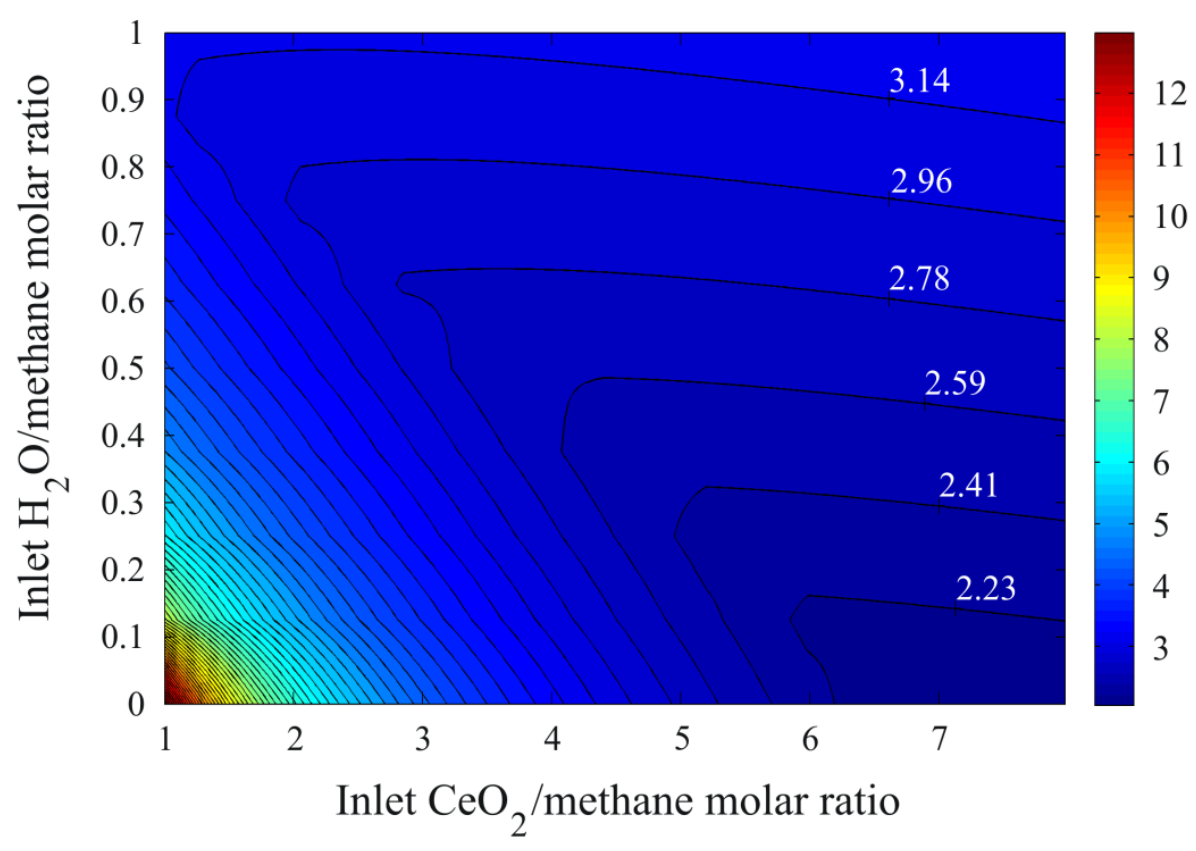

Figure 2. Equilibrium $\mathrm{H}_{2} / \mathrm{CO}$ molar ratio as a function of inlet $\mathrm{H}_{2} \mathrm{O}$ /methane and $\mathrm{CeO}_{2} /$ methane molar ratios. $T=1023 \mathrm{~K}$.

\subsection{Effect of Ceria Redox Properties on Biogas Conversion}

Figure 3 (a)-(d) shows the equilibrium composition (partial pressure of anode species $\left(\mathrm{H}_{2}, \mathrm{CO}, \mathrm{CO}_{2}, \mathrm{H}_{2} \mathrm{O}, \mathrm{CH}_{4}, \mathrm{O}_{2}\right)$ and number of moles of condensed phases ( graphite and $\left.\mathrm{CeO}_{1.83}\right)$ ) as a function of inlet $\mathrm{CeO}_{2} /$ biogas molar ratio at $T=1023 \mathrm{~K}$. Figure 3 (a)(c) refers to methane-rich biogas $\left(\mathrm{CH}_{4} / \mathrm{CO}_{2} / \mathrm{H}_{2}=70: 25: 5\right)$ and Figure 3 (b)-(d) stands for quasi-equimolar reactant composition $\left(\mathrm{CH}_{4} / \mathrm{CO}_{2} / \mathrm{H}_{2}=50: 45: 5\right)$. In both cases, biogas is contaminated with $300 \mathrm{ppm} \mathrm{H}_{2} \mathrm{~S}$. One can see that partial pressure of oxygen in the gas phase increases with the inlet $\mathrm{CeO}_{2} /$ methane molar ratio due to the increase in the number of moles of lattice oxygen released to the anode atmosphere. Carbon deposition region disappears with increased inlet $\mathrm{CeO}_{2} /$ biogas molar ratio. Partial pressure of $\mathrm{CO}$ increases within carbon deposition region, due to gasification of solid carbon promoted by lattice oxygen of ceria. Only after carbon deposition region $\mathrm{H}_{2} \mathrm{O}$ and $\mathrm{CO}_{2}$ increase, due to reaction of $\mathrm{H}_{2}$ and $\mathrm{CO}$ with lattice oxygen, respectively. By comparing the profiles of partial pressures and moles of carbon as a function of the amount of $\mathrm{CeO}_{2}$ in the system with those profiles, obtained in our previous work [15], which were shown as a function of current density, one can see that they are very similar. This fact suggests that the fuel molecules can be oxidized at ceria surface by the lattice oxygen. The ions $\mathrm{O}^{2-}$ are responsible for the continuous regeneration of ceria in its oxidized form. Actually, this fact could be related to the Mars-Van Krevelen mechanism, with ceria being reduced by the fuel and then reoxidized by oxygen ions that come from cathode to the anode, through the electrolyte. The oxygen ions arrive at the anode and replenish the surface oxygen vacancies. The electrons released by oxygen ions are transported into the current collector through the ceria bulk and neutral oxygen atoms are responsible for conversion of methane [16]. Basically, ceria is the oxidation catalyst, responsible for the conversion of methane, which is corroborated in the present work by the results showing the effect of the redox properties of ceria on the equilibrium

\footnotetext{
* Technical contribution to the $69^{\text {th }}$ ABM International Annual Congress and to the ENEMET, July $21^{\text {st }}-25^{\text {th }}$, 2014, São Paulo, SP, Brazil.
} 


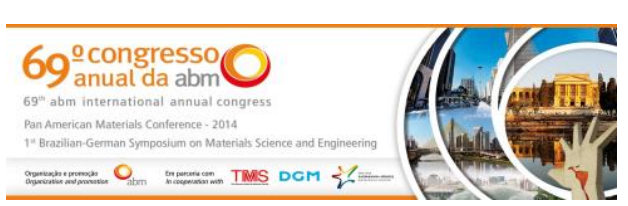

composition during methane conversion. Thus, the reaction can occur in an extended surface, not being limited to the punctual region of triple-phase boundary. In fact, for the same biogas mixtures considered in this theoretical work, Fuerte et al. [3] experimentally corroborated that, for a Cu-ceria-based SOFC anode, stable operation can be achieved at $1023 \mathrm{~K}$.

(a)

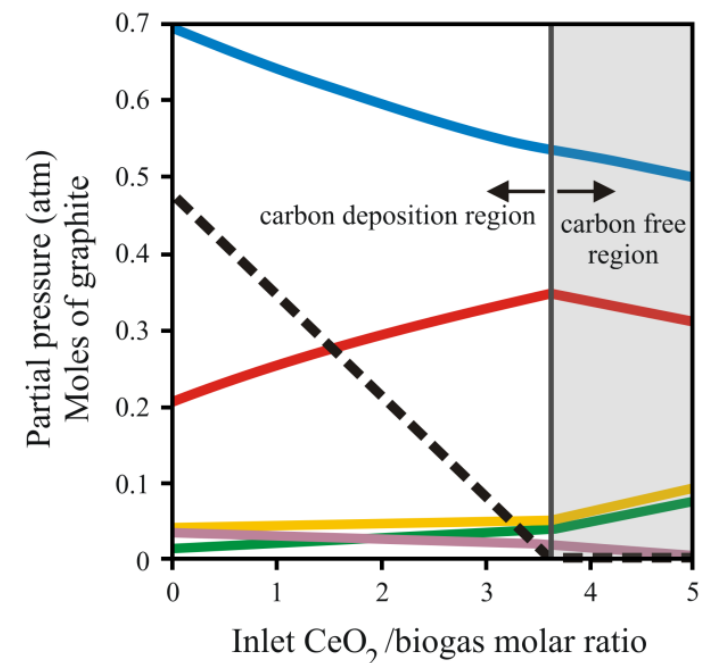

(b)

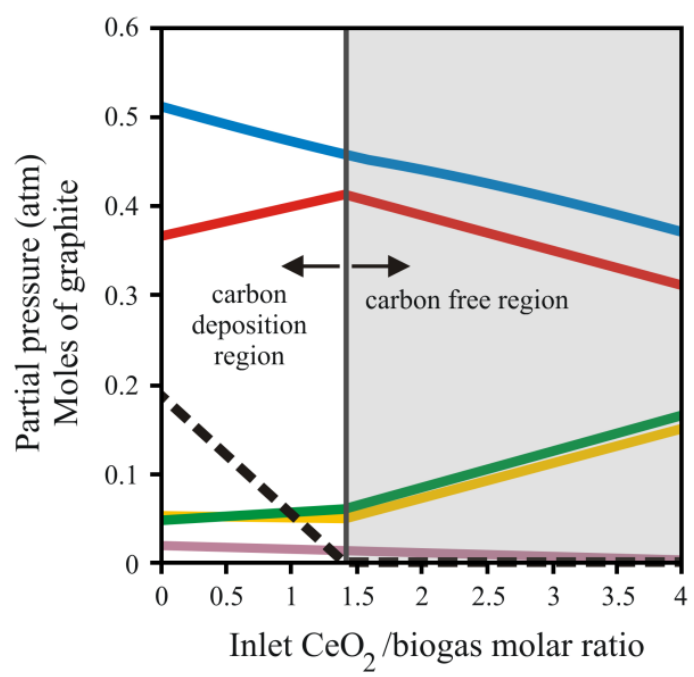

$$
=\mathrm{H}_{2}=\mathrm{CO}=\mathrm{CO}_{2}=\mathrm{H}_{2} \mathrm{O}=\mathbf{-}=\mathrm{C}_{(\mathrm{s})}=\mathrm{CH}_{4}
$$

(c)

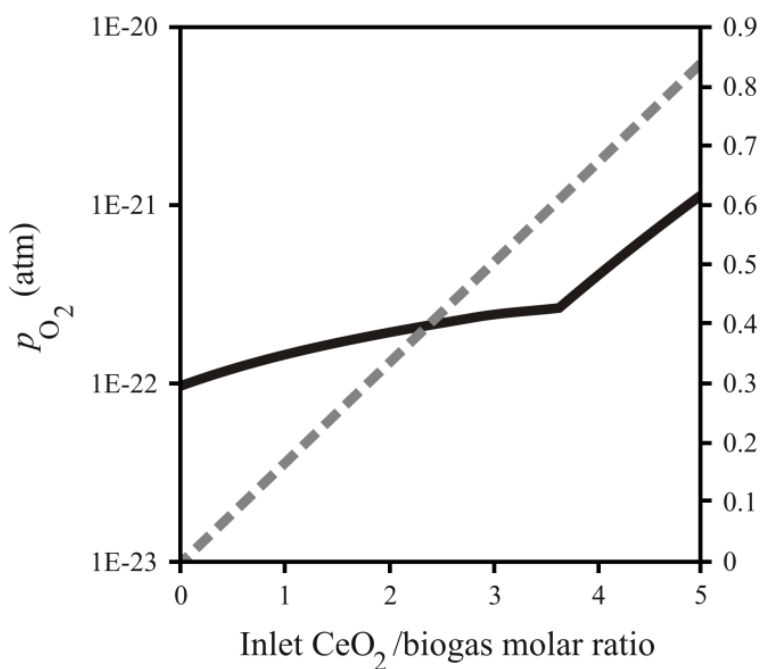

(d)

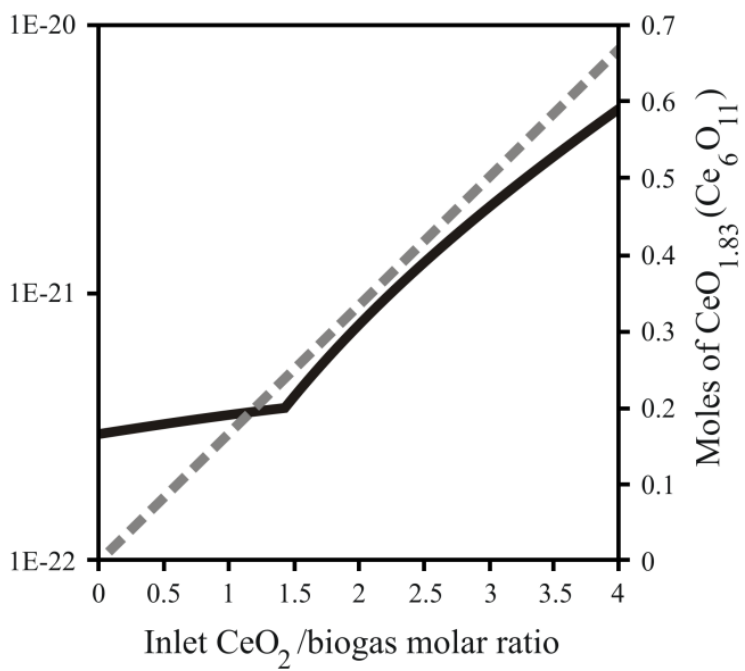

$$
\text { 블 } \mathrm{CeO}_{1.83} \longrightarrow \mathrm{O}_{2}(\mathrm{~atm})
$$

Figure 3. Partial pressures of anode species and moles of graphite as a function of inlet $\mathrm{CeO}_{2} /$ biogas molar ratio ((a) and (b)). Partial pressure of $\mathrm{O}_{2}$ and moles of $\mathrm{CeO}_{1.83}$ as a function of inlet $\mathrm{CeO}_{2} /$ biogas molar ratio ((c) and (d)). Left panel ((a) and (c)) stands for methane-rich biogas $\left(\mathrm{CH}_{4} / \mathrm{CO}_{2} / \mathrm{H}_{2}=70: 25: 5\right)$ and right panel ((b) and (d)) stands for quasi-equimolar biogas mixture $\left(\mathrm{CH}_{4} / \mathrm{CO}_{2} / \mathrm{H}_{2}=50: 45: 5\right)$. $T=1023 \mathrm{~K}$. 
At $1023 \mathrm{~K}$, the value at the equilibrium computed for $\log \left(\frac{p_{\mathrm{H}_{2}}}{p_{\mathrm{H}_{2} \mathrm{~S}}}\right)$ is around 3.48 and 3.62 for the investigated biogas mixtures. From Figure 4, one can see that these values fall in the clean $\mathrm{Cu}$ surface region, which corresponds to the values located above the line S-adsorbed $\mathrm{Cu}(001)$. It is worth pointing out the great difference in the sulfur tolerance exhibited by $\mathrm{Ni}$ and $\mathrm{Cu}$ surfaces: $\mathrm{Cu}$ surface allows a concentration of $\mathrm{H}_{2} \mathrm{~S}$ of approximately 10.000 times greater than $\mathrm{Ni}$ surface. This enormous difference is due to the fact that the enthalpy of adsorption is much more negative for $\mathrm{Ni}$ than for $\mathrm{Cu}$ [4]. For $\mathrm{Ni}$, only $0.03 \mathrm{ppm}$ of $\mathrm{H}_{2} \mathrm{~S}$ would be allowed for a stable operation. The diagram shown in Figure 4 was computed by Malyi et al. [17] with the help of Density Functional Theory. Above the respective green lines, clean metal surface is predicted; below the lines, sulfur poisoning is expected. Figure 5 depicts the predominance diagram of Ce-S-O system at 1023K. One can see that for both biogas mixtures, quasi-equimolar (black marker) and methane-rich biogas (white marker), the stability region corresponds to the reduced form of ceria ( $\left.\mathrm{CeO}_{1.83}\right)$. Note that the $\mathrm{Ce}_{2} \mathrm{O}_{2} \mathrm{~S}$ phase, which could limit the ionic conductivity, is not stable under the investigated conditions. It is worth pointing out that, even though in $\mathrm{Cu}-\mathrm{CeO}_{2}$ anode the role of $\mathrm{Cu}$ in catalytic property is negligible, sulfur chemisorption should be avoided, because adsorption on the material surface changes its surface energy inducing changes of agglomeration rate of its particles and metal particle size affects the electrode performance and stability of anode materials [17].

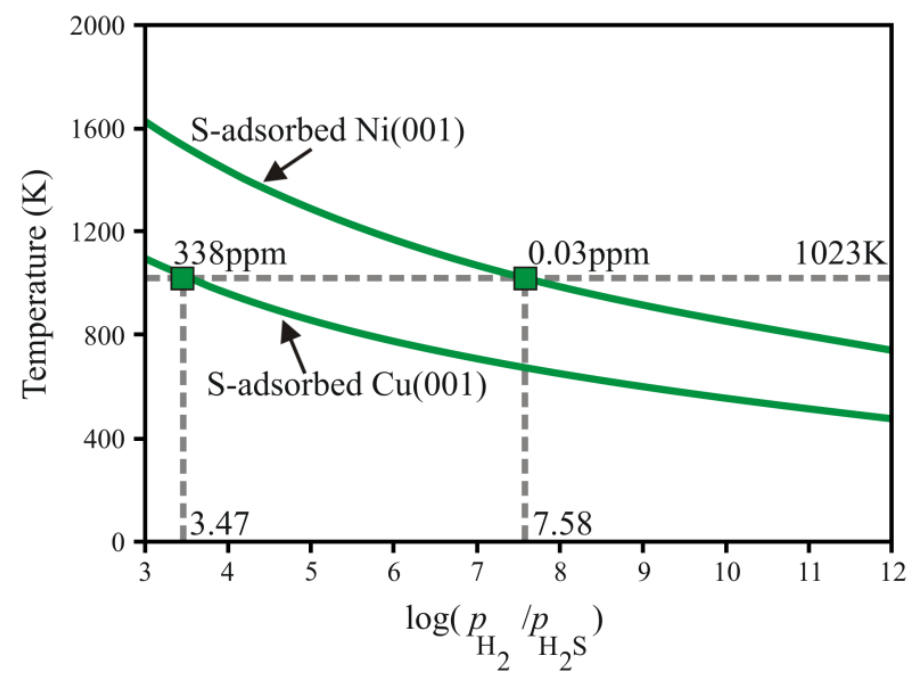

Figure 4. Dependence of the transition temperature between clean and contaminated metal surface on partial pressure ratio of $\mathrm{H}_{2}$ and $\mathrm{H}_{2} \mathrm{~S}$, calculated by Malyi et al. [17] for $\mathrm{Ni}$ and $\mathrm{Cu}$ surfaces. Above the green curve, clean metal surface is stable; below the curve, sulfur poisoning is predicted. The markers stand for the boundary values of $\log \left(\frac{p_{\mathrm{H}_{2}}}{p_{\mathrm{H}_{2} \mathrm{~S}}}\right)$ (or $\mathrm{H}_{2} \mathrm{~S}$ concentration in the $\mathrm{H}_{2}+\mathrm{H}_{2} \mathrm{~S}$ gas) at $1023 K$.

\footnotetext{
* Technical contribution to the $69^{\text {th }}$ ABM International Annual Congress and to the ENEMET, July $21^{\text {st }}-25^{\text {th }}$, 2014, São Paulo, SP, Brazil.
} 


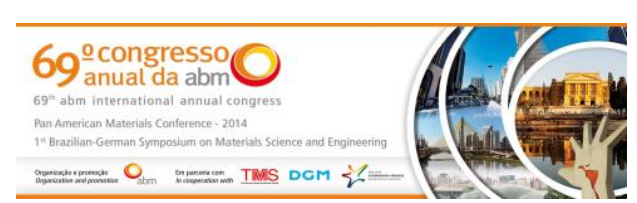

the methane required to avoid the formation of solid carbon. In fact, solid carbon can be totally gasified by the oxygen storage capacity (OSC) of ceria, even in absence of steam in the feedstock. At low inlet $\mathrm{H}_{2} \mathrm{O} / \mathrm{CH}_{4}$ molar ratio and high inlet $\mathrm{CeO}_{2} / \mathrm{CH}_{4}$ molar ratio, the $\mathrm{H}_{2} / \mathrm{CO}$ molar ratio at the equilibrium is near 2.0, which is consistent with the partial oxidation reaction of methane. At an inlet of $\mathrm{H}_{2} \mathrm{O} / \mathrm{CH}_{4}$ molar ratio of 1.0 , the equilibrium $\mathrm{H}_{2} / \mathrm{CO}$ molar ratio is near 3.0, whatever the amount of $\mathrm{CeO}_{2}$ in the system, which suggests that the steam reforming reaction is predominant. Thus, in the $\mathrm{Cu}-\mathrm{CeO}_{2}$ anode, $\mathrm{Cu}$, which is known for exhibiting very low catalytic activity, acts as a current collector, while ceria is the active oxidation catalyst.

- It was found that $\mathrm{Cu}-\mathrm{CeO}_{2}$ anode can run on different biogas compositions (quasi-equimolar reactant composition, with $\mathrm{CH}_{4} / \mathrm{CO}_{2} / \mathrm{H}_{2}=50: 45: 5$, and methane-rich biogas, with $\left.\mathrm{CH}_{4} / \mathrm{CO}_{2} / \mathrm{H}_{2}=70: 25: 5\right)$ contaminated with $300 \mathrm{ppm}$ $\mathrm{H}_{2} \mathrm{~S}$, with no sulfur chemisorption on $\mathrm{Cu}$. Solid carbon can be gasified at an inlet $\mathrm{CeO}_{2} /$ biogas molar ratio of 1.43 and 3.65 , for the quasi-equimolar and methane-rich biogas, respectively, at $1023 \mathrm{~K}$. Thus, carbon deposition and sulfur poisoning could be simultaneously avoided with the use of $\mathrm{Cu}-\mathrm{CeO}_{2}$ anodes. Besides, the bulk $\mathrm{Ce}_{2} \mathrm{O}_{2} \mathrm{~S}$ phase, which could limit the ionic conductivity, is not thermodynamically stable under the investigated conditions. Thus, thermodynamics suggest a stable SOFC operation. On the other hand, in the case of Ni-YSZ, under the same conditions, severe sulfur poisoning of $\mathrm{Ni}$ catalyst is predicted, as well as a system very prone to carbon deposition. Thus, it is expected that power output will be lower for Ni-YSZ anodes, in agreement with experimental reports.

\section{Acknowledgments}

The authors would like to thank FAPERGS (Fundação de Amparo à Pesquisa do Estado do Rio Grande do Sul) and CAPES (Coordenação de Aperfeiçoamento de Pessoal de Nível Superior) for their financial support (Postdoctoral fellowship - Edital 09/2012 - DOCFIX).

\section{REFERENCES}

1 Damyanova S, Pawelec B, Arishtirova K, Fierro JLG. International Journal of Hydrogen Energy. 2011; 36: 10635-10647.

2 Hammad M, Badarneh D, Tahboud K. Energy Conversion and Management. 1999; 40: 1463-1475.

3 Fuerte A., RX Valenzuela, MJ Escudero, L Daza. International Journal of Hydrogen Energy. 2014; 39: 4060-4066.

4 Cheng Z, Wang JH, Choi YM, Yang L, Lin MC, Liu M. Energy \& Environmental Science. 2011; 4: 4380-4409.

$5 \quad$ Singh R, Guzman F, Khatri R, Chuang SSC. Energy \& Fuels. 2010; 24: 1176-1183.

$6 \mathrm{He}$ HP, Gorte RJ, Vohs JM. Electrochemical and Solid-State Letters. 2005; 8: A279A280.

7 Zhao L, Ye X, Zhan Z. Journal of Power Sources. 2011; 196: 6201-6204.

8 EquiSage.ppt. The Equilib module - Regular features. Index of/fact/factsage. www.crct.polymtl.ca/fact/factsage. (accessed October 2013).

9 Bale CW, Chartrand P, Decterov SA, Eriksson G, Hack K, Mahfoud RB, Melançon J, Pelton AD, Petersen S. Calphad. 2002; 26: 189-228.

10 FactSage 6.3 - Summary of Databases. www.crct.polymtl.ca/fact/documentation./FSData.htm. (accessed January 2014).

\footnotetext{
* Technical contribution to the $69^{\text {th }} A B M$ International Annual Congress and to the ENEMET, July $21^{\text {st }}-25^{\text {th }}$, 2014, São Paulo, SP, Brazil.
} 
11 Bale CW, Bélisle E, Chartrand P, Decterov SA, Eriksson G, Hack K, Jung IH, Kang YB, Melançon J, Pelton AD, Robelin C, Petersen S. Calphad. 2009; 33: 295-311.

12 Rostrup-Nielsen JR. Applied Catalysis. 1981; 1: 303-314.

13 Chen XJ, Khor KA, Chan SH. Electrochemistry and Solid-State Letters. 2005; 8: A79.

14 Laosiripojana N, Assabumrungrat S. Journal of Power Sources. 2007; 163: 943.

15 Lima da Silva A, Heck NC. Direct-biogas solid oxide fuel cell (SOFC) - a theoretical

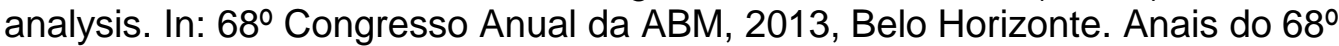
Congresso Anual da ABM, Belo Horizonte: ABM 2013. Pages 1112-1121.

16 Knapp D, Ziegler T. Journal of Physical Chemistry C. 2008; 112: 17311-17318.

17 Malyi OI, Bai K, Kulish VV, Wu P, Chen Z. Chemical Physics Letters. 2012; 533: 20-24.

18 Furtado JGM, Gutierres TEF, Silva AK, Dias R. Materiais para células a combustível de óxido sólido para operação com combustíveis hidrocarbônicos e álcoois - parte II: desempenho e degradação. In: 68ํㅡㄹ Congresso Anual da ABM, 2013, Belo Horizonte. Anais do 68ํㅡㄹ Congresso Anual da ABM, Belo Horizonte: ABM 2013. Pages 91-100. 